\title{
Photophysical and Electrochemical Properties of 1,7-Diaryl-Substituted Perylene Diimides
}

\author{
Chun-Chieh Chao ${ }^{\dagger}$ and Man-kit Leung*,†, \\ Department of Chemistry and Institute of Polymer Science and Engineering, National Taiwan University, \\ Taipei, Taiwan 106, ROC
}

Yuhlong Oliver Su, ${ }^{*}$ Kuo-Yuan Chiu, and Tsung-Hsien Lin

Department of Applied Chemistry, National Chi Nan University, Nantou, Taiwan 545, ROC

Shwu-Ju Shieh and Shien-Chang Lin

RiTdisplay Corporation, Hsin Chu Industrial Park, Taiwan 30351, ROC

mkleung@ntu.edu.tw

Received January 1, 2005

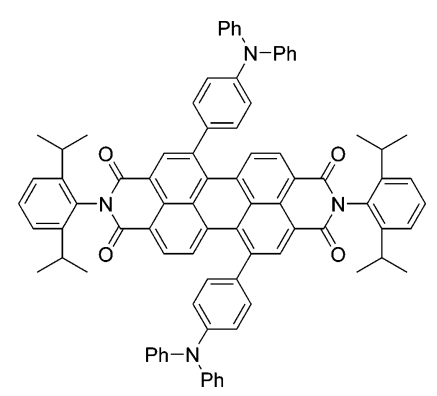

Substituent effects on the photophysical and electrochemical properties of 1,7-diaryl-substituted perylene diimides (1,7-Ar ${ }_{2} \mathrm{PDI}$ ) have been carefully explored. Progressive red-shifts of the absorption and emission maxima were observed when the electron-donating ability of these substituents was increased. Linear Hammett correlations of $1 / \lambda_{\max }$ versus $\sigma^{+}$were observed in both spectral analyses. The positive slopes of the Hammett plots suggested that the electronic transitions carry certain amounts of photoinduced intramolecular charge-transfer (PICT) character from the aryl substituents to the perylene diimide core which leads to the reduction of the electron density on the substituents. The substituent electronic effects originated mainly from the perturbation of the core PDI HOMO energy level by the substituents. This conclusion was supported by PM3 analyses and confirmed by cyclic voltammetry experiments. More interestingly, the $\mathrm{Ph}_{2} \mathrm{NC}_{6} \mathrm{H}_{4}$-substituted PDI, 4i, showed an unusual dual-band absorption that spans from 450 to $750 \mathrm{~nm}$. We tentatively assigned these two bands as the charge-transfer band and the PDI core absorption, respectively.

\section{Introduction}

During the past few decades, conversion of solar energy into electricity has been one of the important areas for scientific research. ${ }^{1}$ Today's silicon solar cells can convert up to $24 \%$ of the terrestrial solar energy into electrical energy and have been already commercialized for many applications. ${ }^{2}$ However, the solar cell's production usually involves high-temperature processes as well as numerous lithographic steps. ${ }^{3}$ Therefore, solar cells made from

\footnotetext{
$\dagger$ Department of Chemistry.

$\ddagger$ Institute of Polymer Science and Engineering.
}

organic semiconducting thin films have become attractive alternatives to investigate. Organic semiconductors can conduct charges through partial delocalization or charge hopping between molecules. ${ }^{4}$ Cells made from organic semiconductors have been of interest as photovoltaic light emitting devices, field effect transistors, and memories. ${ }^{5}$ Current organic solar cells have reached solar power efficiencies of about $2 \%$ with corresponding external quantum efficiency peaks at about $50 \% .^{6}$

One important factor that governs the performance of a solar cell is the absorption spectrum of the organic semiconductors or the dye molecules used for device 


\section{SCHEME 1. Synthesis of 1,7-Ar 2 PDIs}
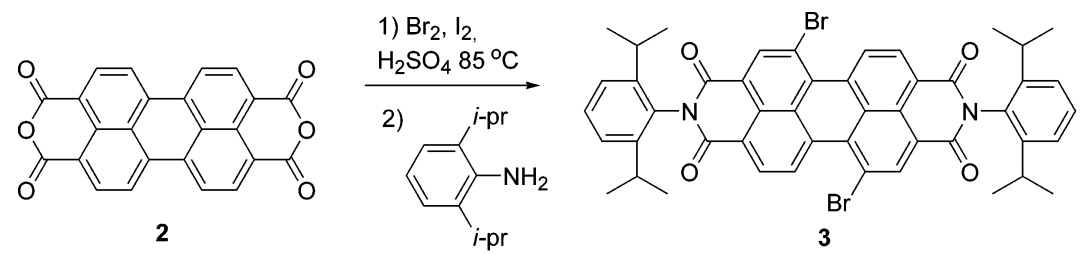

NMP, $\mathrm{HOAc}, 120^{\circ} \mathrm{C}$
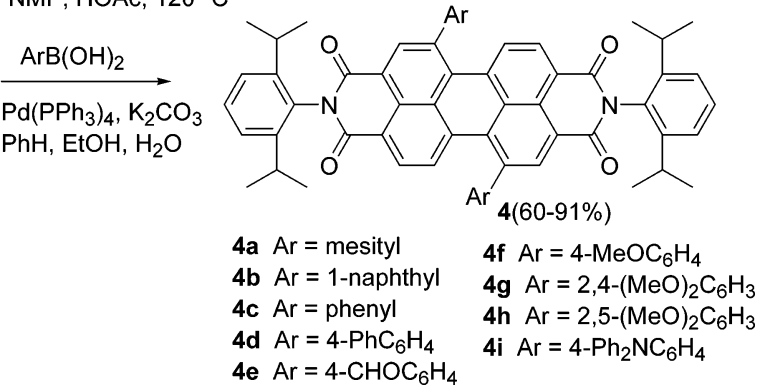

fabrication. In an ideal situation, the solar cell absorption spectrum should completely cover the region of terrestrial solar irradiation. ${ }^{7}$ Therefore, the development of novel dye molecules with appropriate absorptive properties for photon harvesting has become an important area to explore. Organic dyes usually absorb photons through allowed $\pi-\pi^{*}$ or $\mathrm{n}-\pi^{*}$ electronic transitions. Unfortunately, the absorption bands of organic chromophores are usually narrow and unable to cover the whole visible region. Therefore, multichromophoric materials have recently been developed. ${ }^{8}$

Perylene diimides (PDIs) are important electron acceptors and electron-transporting materials that have been used in various dimensions. In particular, PDIs show unusual photocurrent amplification properties and are potentially useful compounds for solar cell applications. ${ }^{9}$ Therefore, it is extremely crucial to understand the photophysical properties of PDIs.

(1) (a) Coakley, K. M.; McGehee, M. D. Chem. Mater. 2004, 16, 4533-4542. (b) Veenstra, S. C.; Verhees, W. J. H.; Kroon, J. M.; Koetse, M. M.; Sweelssen, J.; Bastiaansen, J. J. A. M.; Schoo, H. F. M.; Yang, X.; Alexeev, A.; Loos, J.; Schubert, U. S.; Wienk, M. M. Chem. Mater. 2004, 16, 2503-2508. (c) Imahori, H.; Fukuzumi, S. Adv. Funct. Mater. 2004, 14, 525-536. (d) Kannan, B.; Castelino, K.; Majumdar, A. Nano Lett. 2003, 3, 1729-1733. (e) Sun, B.; Marx, E.; Greenham, N. C. Nano Lett. 2003, 3, 961-963. (f) Tokuhisa, H.; Hammond, P. T. Adv. Funct. Mater. 2003, 13, 831-839. (g) Wienk, M. M.; Kroon, J. M.; Verhees, W. J. H.; Knol, J.; Hummelen, J. C.; van Hal, P. A.; Janssen, R. A. J. Angew. Chem., Int. Ed. 2003, 42, 3371-3375. (h) van Hal, P. A.; Wienk, M. M.; Kroon, J. M.; Verhees, W. J. H.; Slooff, L. H.; van Gennip, W. J. H.; Jonkheijm, P.; Janssen, R. A. J. Adv. Mater. 2003, 15, 118-121. (i) Kim, Y.-G.; Walker, J.; Samuelson, L. A.; Kumar, J. Nano Lett. 2003, 3, 523-525. (j) Eckert, J.-F.; Nicoud, J.-F.; Nierengarten, J.-F.; Liu, S.-G.; Echegoyen, L.; Barigelletti, F.; Armaroli, N.; Ouali, L.; Krasnikov, V.; Hadziioannou, G. J. Am. Chem. Soc. 2000, 122, 7467-7479. (k) Zhang, F.; Johansson, M.; Andersson, M. R.; Hummelen, J. C.; Inganäs, O. Adv. Mater. 2002, 14, 662-665. (1) Snaith, H. J.; Arias, A. C. Morteani, A. C.; Silva, C.; Friend, R. H. Nano Lett. 2002, 2, 13531357.

(2) (a) Green, M. A. Adv. Mater. 2001, 13, 1019-1022. (b) Schultz, O.; Glunz, S. W.; Willeke, G. P. Prog. Photovoltaics 2004, 12, 553558. (c) Green, M. A.; Emery, K.; King, D. L.; Igari, S.; Warta, W. Prog. Photovoltaics 2004, 12, 365-372.

(3) (a) MacDiarmid, A. G. Angew. Chem., Int. Ed. 2001, 40, 25812590. (b) Ozin, G. A.; Yang, S. M. Adv. Funct. Mater. 2001, 11, 95104 (c) Gonsalves, K. E.; Merhari, L.; Wu, H.; Hu, Y. Adv. Mater. 2001, 13, 703-714. (d) Zhong, Z.; Gates, B.; Xia, Y.; Qin, D. Langmuir 2000, $16,10369-10375$

(4) (a) Sutin, N.; Brunschwig, B. S.; Creutz, C.; Feldberg, S. W. J. Phys. Chem. B 2004, 108, 12092-12102. (b) Heeney, M.; Bailey, C.; Giles, M.; Shkunov, M.; Sparrowe, D.; Tierney, S.; Zhang, W.; McCulloch, I. Macromolecules 2004, 37, 5250-5256. (c) Gregg, B. A. J. Phys. Chem. B 2003, 107, 4688-4698.

The parent PDI 1 shows a vibronic absorption band at $450-550 \mathrm{~nm}^{10}$

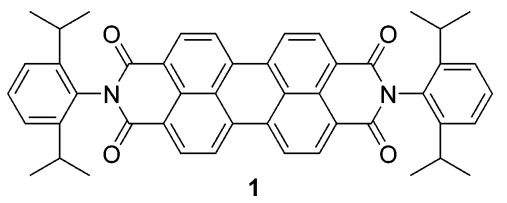

This absorption range is important because it is located in the middle of the visible region. However, the bandwidth is not wide enough to cover the spectral range. Introduction of conjugated substituents onto the perylene core is known to perturb the orbital energy of the perylene $\pi$-array and usually leads to a shift of the absorption maximum. ${ }^{11}$ Nevertheless, the width of the absorption band would not be significantly expanded. Recently, imido $N$-substituent effects and multichromophoric perylene diimides with wide spectral responses have been investigated and reported. ${ }^{12}$ In our report, we have described the synthesis and chromophoric behavior of 1,7-diaryl-substituted PDIs (1,7-Ar $\left.{ }_{2} \mathrm{PDIs}\right)$.

\section{Results and Discussion}

The synthesis of $1,7-\mathrm{Ar}_{2} \mathrm{PDIs}$ began with the $\mathrm{I}_{2}$ catalyzed bromination of 3,4,9,10-perylenetetracarboxylic dianhydride (2) in $98 \%$ concentrated sulfuric acid (Scheme 1). ${ }^{13}$ As mentioned in previous literature, high-field ${ }^{1} \mathrm{H}$ NMR analysis revealed that the crude product contained about $75 \%$ of the desired 1,7 -isomers along with $25 \%$ of another unidentified isomer. ${ }^{13 a, 14}$ Because of the low solubility of the crude product, purification of the dibromide is difficult. Therefore, the crude product was subjected to imidization without further purification. Imidization of the anhydride with 2,6-diisopropylaniline was carried out in acetic acid to smoothly produce diimide 3. The unidentified isomer could be easily removed by recrystallization from toluene at this step. Suzuki coupling is known to be an effective approach for introducing aryl side groups to the perylene diimide core. ${ }^{11 a, 15}$ Even though steric hindrance is expected to be high, Suzuki coupling of $\mathbf{3}$ with various boronic acids successfully produces 4 in high yields in our study.

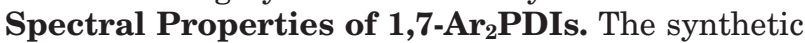
yields of the 1,7-Ar ${ }_{2} \mathrm{PDIs}$ prepared and their photophysi- 
TABLE 1. Synthetic Yields and Photophysical Properties of $\mathrm{Ar}_{2} \mathrm{PDIs}$

\begin{tabular}{|c|c|c|c|c|c|c|}
\hline compd & $\mathrm{Ar}$ & yield & $\lambda_{\max }(\mathrm{abs})$ & $\log \epsilon^{a}$ & $\lambda_{\max }(\mathrm{fl})$ & $\mathrm{Qy}^{b}$ \\
\hline $\mathbf{1}$ & $\mathrm{H}$ & $-^{c}$ & 527 & 4.90 & 534 & 1 \\
\hline 3 & $\mathrm{Br}$ & 36 & 528 & 4.68 & 547 & 0.76 \\
\hline $4 \mathbf{a}$ & mesityl & 73 & 534 & 4.76 & 577 & 0.68 \\
\hline $4 b$ & 1-naphthyl & 80 & 540 & 4.60 & 625 & 0.30 \\
\hline $4 c$ & phenyl & 90 & 556 & 4.62 & 594 & 0.61 \\
\hline 4d & $4-(\mathrm{Ph}) \mathrm{C}_{6} \mathrm{H}_{4}$ & 91 & 566 & 4.65 & 624 & 0.38 \\
\hline $4 e$ & $4-(\mathrm{OCH}) \mathrm{C}_{6} \mathrm{H}_{4}$ & 70 & 550 & 4.63 & 587 & 0.55 \\
\hline $4 f$ & 4- $(\mathrm{MeO}) \mathrm{C}_{6} \mathrm{H}_{4}$ & 66 & 573 & 4.50 & 635 & 0.14 \\
\hline $4 g$ & 2,4-(MeO) $)_{2} \mathrm{C}_{6} \mathrm{H}_{3}$ & 70 & 563 & 4.50 & 640 & 0.08 \\
\hline $4 \mathrm{~h}$ & $2,5-(\mathrm{MeO})_{2} \mathrm{C}_{6} \mathrm{H}_{3}$ & 71 & 542 & 4.53 & - & - \\
\hline $4 \mathbf{i}$ & $4-\left(\mathrm{Ph}_{2} \mathrm{~N}\right) \mathrm{C}_{6} \mathrm{H}_{4}$ & 60 & 512,653 & $4.57,4.13$ & - & - \\
\hline
\end{tabular}

${ }^{a} \epsilon$ is the extinction coefficient in $\mathrm{M}^{-1} \mathrm{~cm}^{-1} \cdot{ }^{b} \mathrm{Qy}$ is the quantum yield. ${ }^{c}$ Authentic sample.

cal properties are summarized in Table 1 . All of these compounds are highly soluble in various organic solvents, such as $\mathrm{CH}_{2} \mathrm{Cl}_{2}, \mathrm{CHCl}_{3}, \mathrm{PhMe}$, and $\mathrm{Me}_{2} \mathrm{CO}$. The parent PDI shows an absorption band peak at $527 \mathrm{~nm}$ with characteristic vibronic fine structure (Figure 1) which is

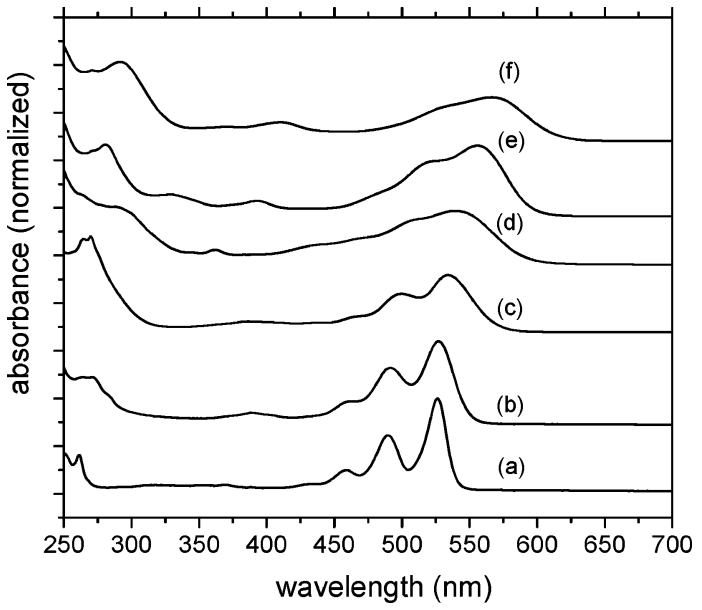

FIGURE 1. Normalized UV-vis absorption spectra for (a) 1 $\left(\lambda_{\max }=527 \mathrm{~nm}\right)$, (b) $3\left(\lambda_{\max }=528 \mathrm{~nm}\right)$, (c) $4 \mathbf{a}\left(\lambda_{\max }=534 \mathrm{~nm}\right)$, (d) $4 \mathbf{b}\left(\lambda_{\max }=540 \mathrm{~nm}\right)$, (e) $4 \mathbf{c}\left(\lambda_{\max }=556 \mathrm{~nm}\right)$, and (f) $4 \mathbf{d}\left(\lambda_{\max }\right.$ $=566 \mathrm{~nm})$ in $\mathrm{CHCl}_{3}$.

attributed to the perylene core $\pi-\pi^{*}$ transition. Similar absorptive features are observed for the Br- and mesitylsubstituted PDIs, $\mathbf{3}$ and $\mathbf{4 a}$, respectively. Because of the steric restriction caused by the methyl substituents, the orientation of the mesityl ring is restricted orthogonally to the perylene ring, and hence, the $\pi$-conjugative interactions are minimal. As a consequence, the $\lambda_{\max }$ of $\mathbf{4 a}$ is only shifted slightly by $7 \mathrm{~nm}$ to $534 \mathrm{~nm}$.

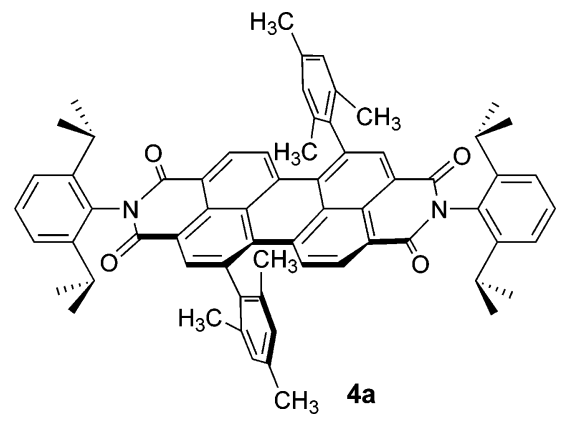

For the 1-naphthyl-substituted PDI 4b, two conformational diastereomers in a 1:1 ratio are observed from the

\section{SCHEME 2. Schematic Diagrams for anti-4b and} syn-4b
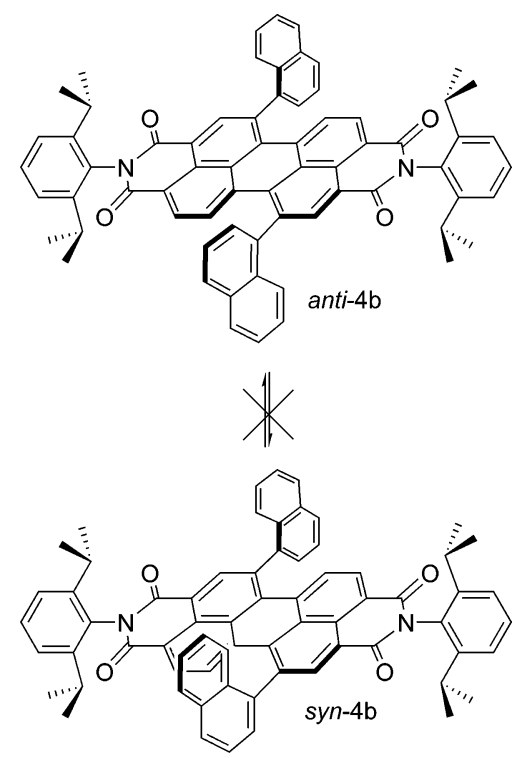

NMR analysis. We tentatively assigned them to the syn and anti forms. Perhaps because of a large restricted rotational energy barrier, the orientation of the naphthyl groups is also restricted perpendicularly to the perylene units. Interconversion between the syn and anti forms is hindered at room temperature, and thus, the red-shift effect in this case is also small (Scheme 2).

When the mesityl rings were replaced by phenyl groups, there were less steric restrictions on the dihedral

(5) (a) Li, A. D. Q.; Li, L. S. J. Phys. Chem. B 2004, 108, 1284212850. (b) Haque, S. A.; Park, T.; Xu, C.; Koops, S.; Schulte, N.; Potter, R. J.; Holmes, A. B.; Durrant, J. R. Adv. Funct. Mater. 2004, 14, 435440. (c) Anthopoulos, T. D.; Frampton, M. J.; Namdas, E. B.; Burn, P. L.; Samuel, I. D. W. Adv. Mater. 2004, 16, 557-560. (d) Kwon, T. W.; Alam, M. M.; Jenekhe, S. A. Chem. Mater. 2004, 16, 4657-4666. (e) Chen, X. L.; Lovinger, A. J.; Bao, Z.; Sapjeta, J. Chem. Mater. 2001, 13, 1341-1348. (f) Xiao, K.; Liu, Y.; Huang, X.; Xu, Y.; Yu, G.; Zhu, D. J. Phys. Chem. B 2003, 107, 9226-9230. (g) Ponomarenko, S. A.; Kirchmeyer, S.; Elschner, A.; Huisman, B.-H.; Karbach, A.; Drechsler, D. Adv. Funct. Mater. 2003, 13, 591-596. (h) Meng, H.; Zheng, J.; Lovinger, A. J.; Wang, B.-C.; Van Patten, P. G.; Bao, Z. Chem. Mater. 2003, 15, 1778-1787. (i) Ito, K.; Suzuki, T.; Sakamoto, Y.; Kubota, D.; Inoue, Y.; Sato, F.; Tokito, S. Angew. Chem., Int. Ed. 2003, 42, 11591162. (j) Veres, J.; Ogier, S. D.; Leeming, S. W.; Cupertino, D. C.; Khaffaf, S. M. Adv. Funct. Mater. 2003, 13, 199-204. (k) Katz, H. E.; Bao, Z.; Gilat, S. L. Acc. Chem. Res. 2001, 34, 359-369. (1) Videlot, C.; Ackermann, J.; Blanchard, P.; Raimundo, J.-M.; Frère, P.; Allain, M.; de Bettignies, R.; Levillain, E.; Roncali, J. Adv. Mater. 2003, 15, 306310. (m) Mushrush, M.; Facchetti, A.; Lefenfeld, M.; Katz, H. E.; Marks, T. J. J. Am. Chem. Soc. 2003, 125, 9414-9423. (n) Kim, S. H.; Yang, Y. S.; Lee, J. H.; Lee, J.-I.; Chu, H. Y.; Lee, H.; Oh, J.; Do, L.-M.; Zyung, T. Opt. Mater. 2002, 21, 439-443. 
angle. The phenyl groups of $\mathbf{4 c}$ are allowed to rotate more freely leading to better $\pi$-orbital overlapping with the perylene core. This leads to a significant red-shift in the absorption spectrum in which the $\lambda_{\max }$ is shifted by 22 $\mathrm{nm}$ to $556 \mathrm{~nm}$. Moreover, the vibronic pattern of the absorption spectrum becomes less clear. A further redshift of the $\lambda_{\max }$ of biphenyl-substituted PDI 4d to 566 $\mathrm{nm}$ implies that $\pi$-conjugation could be further extended in the biphenyl unit.

The spectral-broadening phenomena shown in Figure 1 , from line (a) to line (f), could be attributed to two reasons. One could be the increase of the conjugation between the substituents and the perylene core. ${ }^{11} \mathrm{An}$ other could be the twisting of the perylene core by the substituents so that the vibronic structure is lost. ${ }^{16}$ Previous X-ray crystallographic analyses ${ }^{14,16}$ revealed that the PDI core should be twisted by the bay substituents at the 1,7-positions. If one compares the spectra of $\mathbf{1}$ (line a) against $\mathbf{4 a}$ (line c), in which the $\pi$-conjugation is minimal, one can observe the twisting effect of the PDI core on spectral broadening. However, further spectral

(6) (a) Schmidt-Mende, L.; Fechtenkötter, A.; Müllen, K.; Moons, E.; Friend, R. H.; MacKenzie, J. D. Science 2001, 293, 1119-1122. (b) Vangeneugden, D. L.; Vanderzande, D. J. M.; Salbeck, J.; van Hal, P. A.; Janssen, R. A. J.; Hummelen, J. C.; Brabec, C. J.; Shaheen, S. E.; Sariciftci, N. S. J. Phys. Chem. B 2001, 105, 11106-11113.

(7) Hagfeldt, A.; Grätzel, M. Acc. Chem. Res. 2000, 33, 269-277.

(8) (a) Beckers, E. H. A.; Meskers, S. C. J.; Schenning, A. P. H. J.; Chen, Z.; Wûrthner, F.; Janssen, R. A. J. J. Phys. Chem. A 2004, 108, 6933-6937. (b) Law, K. Y. Chem. Rev. 1993, 93, 449-486.

(9) (a) Wûrthner, F.; Chen, Z.; Hoeben, F. J. M.; Osswald, P.; You, C.-C.; Jonkheijm, P.; Herrikhuyzen, J. v.; Schenning, A. P. H. J.; van der Schoot, P. P. A. M.; Meijer, E. W.; Beckers, E. H. A.; Meskers, S. C. J.; Janssen, R. A. J. J. Am. Chem. Soc. 2004, 126, 10611-10618. (b) Gregg, B. A. J. Phys. Chem. 1996, 100, 852-859. (c) Salaneck, W. R.; Seki, K.; Kahn, A.; Pireaux, J. J. Conjugated Polymer and Molecular Interfaces; Marcel Dekker: New York, 2001. (d) Neuteboom, E. E.; van Hal, P. A.; Janssen, R. A. J. Chem.-Eur. J. 2004, 10, 3907-3918. (e) Hua, J.; Meng, F.; Ding, F.; Li, F.; Tian, H. J. Mater. Chem. 2004, 14 1849-1853. (f) You, C.-C.; Saha-Möller, C. R.; Würthner, F. Chem. Commun. 2004, 18, 2030-2031.

(10) (a) Geerts, Y.; Quante, H.; Platz, H.; Mahrt, R.; Hopmeier, M.; Böehm, A.; Müllen, K. J. Mater. Chem. 1998, 8, 2357-2369. (b) Holtrup, F.; Müller, G. R.; Quante, H.; De Feyter, S.; De Schryver, F. C.; Müllen, K. Chem.-Eur. J. 1997, 3, 219-225. (c) Seybold, G.; Wagenblast, G. Dyes Pigm. 1989, 11, 303-317.

(11) (a) Sugiyasu, K.; Fujita, N.; Shinkai, S. Angew. Chem., Int. Ed. 2004, 43, 1229-1233. (b) Kohl, C.; Weil, T.; Qu, J.; Müllen, K. ChemEur. J. 2004, 10, 5297-5310.

(12) (a) Ahrens, M. J.; Sinks, L. E.; Rybtchinski, B.; Liu, W.; Jones, B. A.; Giaimo, J. M.; Gusev, A. V.; Goshe, A. J.; Tiede, D. M.; Wasielewski, M. R. J. Am. Chem. Soc. 2004, 126, 8284-8294. (b) Wang, Z. Y.; Qi, Y.; Gao, J. P.; Sacripante, G. G.; Sundararajan, P. R.; Duff, J. D. Macromolecules 1998, 31, 2075-2079. (c) Langhals, H.; Jona, W. Angew. Chem., Int. Ed. 1998, 37, 952-955. (d) Würthner, F.; Thalacker, C.; Sautter, A. Adv. Mater. 1999, 11, 754-758. (e) Langhals, H.; Saulich, S. Chem.-Eur. J. 2002, 8, 5630-5643. (f) Schweitzer, G.; Gronheid, R.; Jordens, S.; Lor, M.; De Belder, G.; Weil, T.; Reuther, E.; Müllen, K.; De Schryver, F. C. J. Phys. Chem. A 2003, 107, 31993207. (g) Langhals, H.; Ismael, R.; Yürük, O. Tetrahedron 2000, 56, 5435-5441. (h) Guo, X.; Zhang, D.; Zhang, H.; Fan, Q.; Xu, W.; Ai, X.; Fan, L.; Zhu, D. Tetrahedron 2003, 59, 4843-4850.

(13) (a) Rohr, U.; Kohl, C.; Müllen, K.; van de Craats, A.; Warman, J. J. Mater. Chem. 2001, 11, 1789-1799. (b) Böehm, A.; Arms, H.; Henning, G.; Blaschka, P. U.S. Patent 6184378, 2001. (c) Böehm, A.; Arms, H.; Henning, G.; Blaschka, P. U.S. Patent 6063181, 2000.

(14) Würthner, F.; Stepanenko, V.; Chen, Z.; Saha-Möller, C. R.; Kocher, N.; Stalke, D. J. Org. Chem. 2004, 69, 7933-7939.

(15) (a) Ahrens, M. J.; Fuller, M. J.; Wasielewski, M. R. Chem. Mater. 2003, 15, 2684-2686. (b) Serin, J. M.; Brousmiche, D. W. Fréchet, J. M. J. Chem. Commun. 2002, 2605-2607. (c) Rohr, U.; Schlichting, P.; Böhm, A.; Gross, M.; Meerholz, K.; Bräuchle, C.; Müllen, K. Angew. Chem., Int. Ed. 1998, 37, 1434-1437. (d) Miyaura, N.; Suzuki, A. Chem. Rev. 1995, 95, 2457-2483.

(16) (a) Osswald, P.; Leusser, D.; Stalke, D.; Würthner, F. Angew. Chem., Int. Ed. 2005, 44, 250-253. (b) Chen, Z.; Debije, M. G.; Debaerdemaeker, T.; Osswald, P.; Würthner, F. ChemPhysChem 2004 $5,137-140$

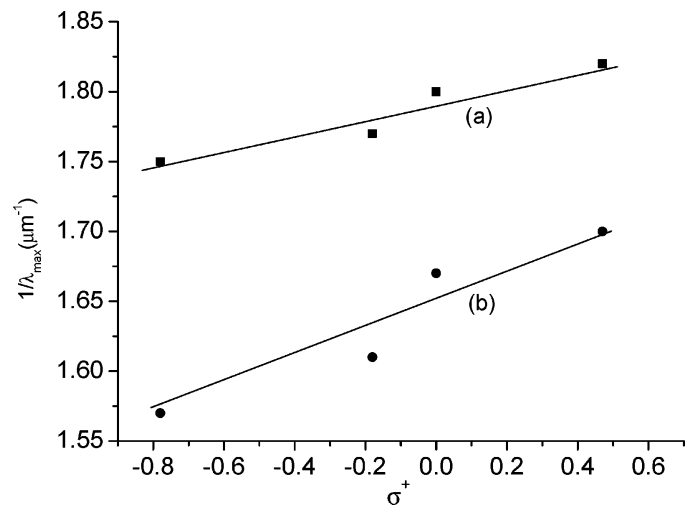

FIGURE 2. Hammett plot of $1 / \lambda_{\max }$ versus $\sigma^{+}$for phenylsubstituted PDIs 4c-4f: (a) absorption and (b) fluorescence.

broadening along with significant red-shifting was observed in the comparison among the spectra of $\mathbf{4 a}$ (line c), 4c (line e), and 4d (line f). Since the steric effects of the phenyl groups of $\mathbf{4 a}, \mathbf{4 c}$, and $\mathbf{4 d}$ on the core twisting should not be significantly different, we tentatively attributed the spectral broadening to the $\pi$-conjugation effects. This argument is also consistent with the results of the semiempirical calculations that will be presented in later sections.

Substituent electronic effects are also observed for 1,7$\mathrm{Ar}_{2} \mathrm{PDI}$. Progressive red-shifts of the absorption maxima occur when the electron-donating ability of the substituents increases. Since the perylene diimide core is known to be a good electron acceptor, photoinduced intramolecular charge transfer (PICT) may occur in this case. The photoinduced electronic transition would reallocate the electron density from the HOMO of the phenyl substituents to the LUMO of the perylene diimide core, re-siding the positive charge density on the phenyl substituents. ${ }^{17}$ In this circumstance, the introduction of electron-donating groups on the phenyl substituents would stabilize the excited state, leading to significant red-shifts on their absorption spectra. This argument is supported by a reasonably good Hammett correlation of $1 / \lambda_{\max }$ versus $\sigma^{+}$for the family of phenyl-substituted PDIs $\mathbf{4 c}, \mathbf{4 d}, 4 \mathbf{e}$, and $4 \mathbf{f}$ with a slope of $\rho_{\mathrm{abs}}=+0.061 \mu \mathrm{m}^{-1}$ (Figure 2). ${ }^{17}$ Compounds $4 \mathbf{c}-\mathbf{4 f}$ were selected because they have similar steric factors and are, therefore, suitable models for comparison. The positive slope here suggested that the electronic transition carries a certain amount of PICT character from the phenyl substituent to the perylene diimide core which reduces the electron density on the phenyl substituent. On the the other hand, the spectral behavior of $\mathbf{4 i}$ is quite different when compared to that of the others. The $1 / \lambda_{\max }$ of $4 \mathbf{i}$ does not align well with the others in the Hammett plot. Furthermore, 4i does not show any observable fluorescent properties. The photophysical properties of $4 \mathbf{i}$ will therefore be discussed separately as another section.

Introduction of methoxy groups to the ortho positions again prohibits the phenyl ring from $\pi$-conjugation and, hence, reduces the red-shift effect on the $\lambda_{\max }$. As we can see in the spectra shown in Figure 3, although $\mathbf{4 g}$ and

(17) (a) Papper, V.; Pines, D.; Likhtenshtein, G.; Pines, E. Photochem. Photobiol. 1997, 111, 87-96. (b) Elango, K. P. Trans. Met. Chem 2004, 29, 125-128. (c) Bonesi, S. M.; Fagnoni, M.; Albini, A. J. Org. Chem. 2004, 69, 928-935 and references therein. 


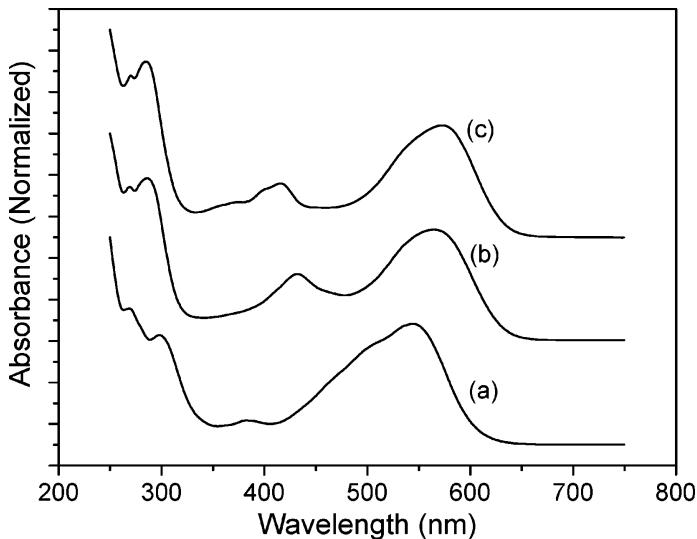

FIGURE 3. Normalized UV-vis absorption spectra for (a) $4 \mathbf{h}$ $\left(\lambda_{\max }=542 \mathrm{~nm}\right),(\mathrm{b}) \mathbf{4 g}\left(\lambda_{\max }=563 \mathrm{~nm}\right)$, and (c) $\mathbf{4 f}\left(\lambda_{\max }=573\right.$ $\mathrm{nm})$ in $\mathrm{CHCl}_{3}$.

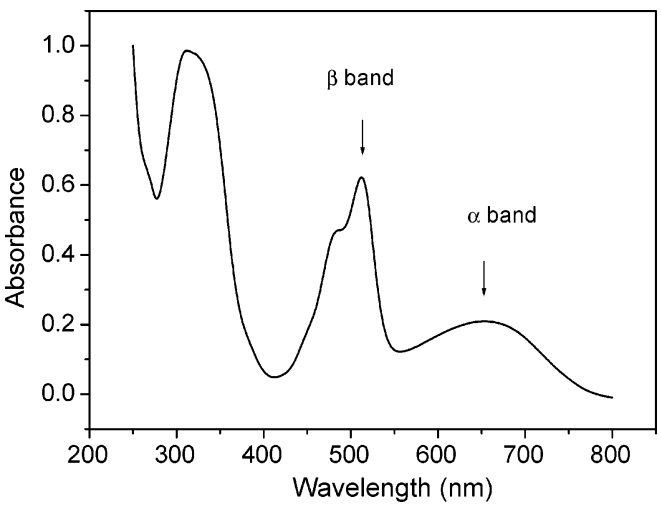

FIGURE 4. UV-vis absorption spectrum of $4 \mathbf{i}$.

4h are supposed to be more electron-rich than $\mathbf{4 f}, \mathbf{4 f}$ has the largest red-shift on the $\lambda_{\max }$ in comparison with that of $\mathbf{4 g}$ and $\mathbf{4 h}$.

More interesting is the fact that the absorption spectrum of $1,7-\left(\mathrm{Ph}_{2} \mathrm{NC}_{6} \mathrm{H}_{4}\right)_{2} \mathrm{PDI}(\mathbf{4 i})$ shows dual bands in visible region, in which the first band, peaked at $653 \mathrm{~nm}$, is denoted as the $\alpha$-band and the second band, peaked at $512 \mathrm{~nm}$, is denoted as the $\beta$-band (Figure 4). The first band is broad and is tentatively attributed to the chargetransfer absorption involving the electronic transition from the $\mathrm{C}_{6} \mathrm{H}_{4} \mathrm{NPh}_{2}$ group to the electron-deficient perylene core. The second band shows a characteristic vibronic coupling pattern and is assigned to the perylene $\pi-\pi^{*}$ transition. The two absorption bands span a wide range of the visible spectrum from 450 to $750 \mathrm{~nm}$. In comparison to the $\lambda_{\max }$ of the parent PDI, $\mathbf{1}$, the $\alpha$-band is shifted by $126 \mathrm{~nm}$ while the $\beta$-band is blue-shifted by $15 \mathrm{~nm}$.

1,7-Ar ${ }_{2} \mathrm{PDIs} \mathbf{4 a}-\mathbf{4 g}$ are fluorescent compounds. Their emissions, $\lambda_{\max }$, are in the 577-640 $\mathrm{nm}$ range and are listed in Table 1. Their fluorescent spectra are shown in Figure 5. Similar substituent electronic effects have also been observed in their fluorescence spectra. A linear Hammett correlation of the $1 / \lambda_{\max }$ and the quantum yields of $4 \mathbf{c}-4 \mathbf{f}$ and $4 \mathbf{i}$ versus $\sigma^{+}$are observed. ${ }^{17}$ The larger slope of $\rho_{\mathrm{fl}}=0.107 \mu \mathrm{m}^{-1}$ (Figure 2) in comparison to $\rho_{\mathrm{abs}}=0.061$ $\mu \mathrm{m}^{-1}$ implies that the emissive excited state involved in the fluorescent process is more susceptible to the substituent electronic effects than that in the absorption process. This observation is consistent with the assump-

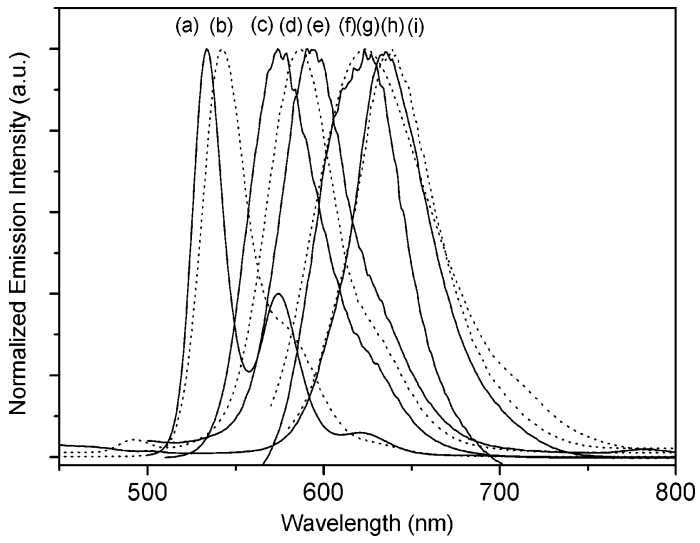

FIGURE 5. Normalized fluorescence spectra in $\mathrm{CHCl}_{3}$ for (a) $1\left(\lambda_{\max }=533 \mathrm{~nm}\right),(\mathrm{b}) \mathbf{3}\left(\lambda_{\max }=547 \mathrm{~nm}\right)$, (c) $4 \mathbf{a}\left(\lambda_{\max }=577\right.$ $\mathrm{nm}),(\mathrm{d}) 4 \mathbf{e}\left(\lambda_{\max }=587 \mathrm{~nm}\right),(\mathrm{e}) 4 \mathbf{c}\left(\lambda_{\max }=594 \mathrm{~nm}\right),(\mathrm{f}) \mathbf{4 d}\left(\lambda_{\max }\right.$ $=624 \mathrm{~nm}),(\mathrm{g}) \mathbf{4 b}\left(\lambda_{\max }=625 \mathrm{~nm}\right)$, (h) $4 \mathbf{f}\left(\lambda_{\max }=635 \mathrm{~nm}\right)$, and (i) $4 \mathrm{~g}\left(\lambda_{\max }=640 \mathrm{~nm}\right)$

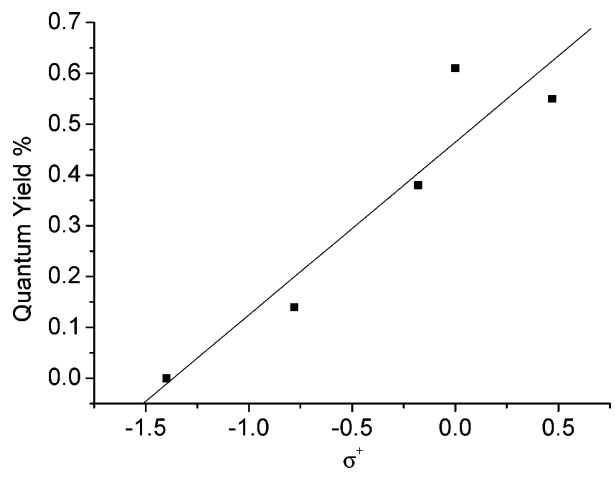

FIGURE 6. Hammett plot of fluorescence quantum yields versus $\sigma$ for phenyl-substituted PDIs $\mathbf{4 c - 4 f}$ and $4 \mathbf{i}$. The correlation coefficient is 0.94 . The quantum yield is assumed to be zero in the plot.

tion that more positive charge will be re-sided onto the aryl substituents in the emissive excited state. In addition, the fluorescence quantum yield drops when the charge-transfer character increases (Figure 6). Therefore, perylene diimides containing electron-rich substituents such as $\mathbf{4 f}$ and $\mathbf{4 g}$ have low photo luminescence quantum yields, and the fluorescence of $\mathbf{4 h}$ and $\mathbf{4 i}$ are undetectable.

To obtain insights into the origin of the spectral behavior, we analyzed the PDIs by semiempirical quantum computations in two ways: (1) optimizing the PDI structures by MM2 methods followed by PM3-RHF calculations for the HOMO and LUMO energies and (2) calculating individually the energy levels of the HOMOs and LUMOs of the perylene diimide core and the side groups by the semiempirical PM3-RHF computations for orbital analysis. To simplify the calculations, we used $N$-methyl groups to replace the large $N$-(2,6-diisopropylphenyl) groups in the calculations.

MM2-PM3 Calculations. The geometry optimizations were carried out by the MM2 method. The energies of the HOMO and LUMO of the corresponding structures were calculated by the PM3 method. The data are summarized in Table 2. As predicted from the literature, ${ }^{14 b, 16}$ the structurally optimized PDI cores are twisted by an angle of $22-25^{\circ}$. The substituents have strong 
TABLE 2. MM2-PM3/RHF Calculation of the HOMO-LUMO Energies of $4 c-4 f$ and $4 i$

\begin{tabular}{cccc}
\hline compd & ${\text { twisting angle }(\mathrm{deg})^{a}}^{a}$ & HOMO (eV) & LUMO (eV) \\
\hline $\mathbf{4 c}$ & 22.3 & -8.717 & -2.405 \\
$\mathbf{4 d}$ & 25.5 & -8.637 & -2.424 \\
$\mathbf{4 e}$ & 23.0 & -8.919 & -2.625 \\
$\mathbf{4 f}$ & 23.8 & -8.615 & -2.388 \\
$\mathbf{4 i}$ & 23.3 & -8.077 & -2.354
\end{tabular}

${ }^{a}$ The average angle from both sides of the optimized structure is not completely symmetrical.

TABLE 3. PM3/RHF Orbital Energies of Molecular Fragments

\begin{tabular}{lcc}
\hline & HOMO $(\mathrm{eV})$ & LUMO $(\mathrm{eV})$ \\
\hline $\mathrm{PDI}$ & -8.90 & -2.48 \\
$\mathrm{Ph}_{3} \mathrm{~N}$ & -7.94 & 0.04 \\
$\mathrm{MeOC}_{6} \mathrm{H}_{5}$ & -9.11 & 0.35 \\
$\left(\mathrm{C}_{6} \mathrm{H}_{5}\right)_{2}$ & -9.12 & -0.17 \\
$\mathrm{C}_{6} \mathrm{H}_{6}$ & -9.75 & 0.40 \\
$\mathrm{CHOC}_{6} \mathrm{H}_{5}$ & -10.15 & -0.75 \\
\hline
\end{tabular}

perturbations on the HOMO energies. The variation of the HOMO energies of $\mathbf{4 c}-\mathbf{4 f}$ is $0.304 \mathrm{eV}$. Unexpected strong perturbation on the HOMO from the electrondonating $\mathrm{Ph}_{2} \mathrm{NC}_{6} \mathrm{H}_{4}$ substituents is observed in the calculation. The HOMO energy of $4 \mathbf{i}$ is $-8.077 \mathrm{eV}$ which is much higher than that of the others. Pictorial orbital analysis revealed that the $\mathrm{HOMOs}$ of $\mathbf{4 c}-\mathbf{4 f}$ originate from the PDI core. However, the HOMO of $4 \mathbf{i}$ originates from the $\mathrm{Ph}_{2} \mathrm{NC}_{6} \mathrm{H}_{4}$ group. On the other hand, the variation of the LUMO energies of $\mathbf{4 c}, \mathbf{4 d}, \mathbf{4 f}$, and $\mathbf{4 i}$ is only $0.07 \mathrm{eV}$, a relatively smaller number than that of the HOMO energies. The LUMO energy of the most electron-deficient compound in the series, $4 \mathbf{e}$, is $2.625 \mathrm{eV}$, which is $0.313 \mathrm{eV}$ lower than that of 4c. Orbital analysis revealed that the LUMO originates from the PDI core, no matter whether the substituents are electron-deficient or electron-rich.

Orbital Analysis. To analyze the orbital interactions between the core and the aryl substituent, we determined the HOMO and LUMO energy levels of the substituent as well as the PDI core. Here, we assumed that the relative orbital energies could be reasonably approximated by the orbital energies of the corresponding molecular fragments. The data of the corresponding molecular fragments are listed in Table 3 . The values for the HOMO and LUMO of the perylene diimide core are obtained on the basis of the assumption that the twisting angle is $22.3^{\circ}$.

As shown in Table 2, the orbital energies of the HOMOs of the $\mathrm{MeOC}_{6} \mathrm{H}_{5}, \mathrm{PhC}_{6} \mathrm{H}_{4}$, and $\mathrm{Ph}$ groups were estimated to be $0.3-0.8 \mathrm{eV}$ lower than that of the perylene core. In these cases, the HOMO-HOMO interactions would raise the energy level of the core PDI HOMO and lower the energy level of the substituent HOMO (Scheme 3, right). On the other hand, the LUMOs of the side groups are $2.3-2.9 \mathrm{eV}$ above the core PDI LUMO so that their interactions would be relatively small. Therefore, we concluded that substituent perturbation raises the HOMO of the PDI core and leads to a red-shift of the absorption spectrum. Since the HOMO of 1,7-Ar ${ }_{2} \mathrm{PDI}$ involves orbital mixing of the substituents and the PDI unit while the LUMO mainly originates from the PDI core, photoexcitation of the HOMO electron onto

\section{SCHEME 3}

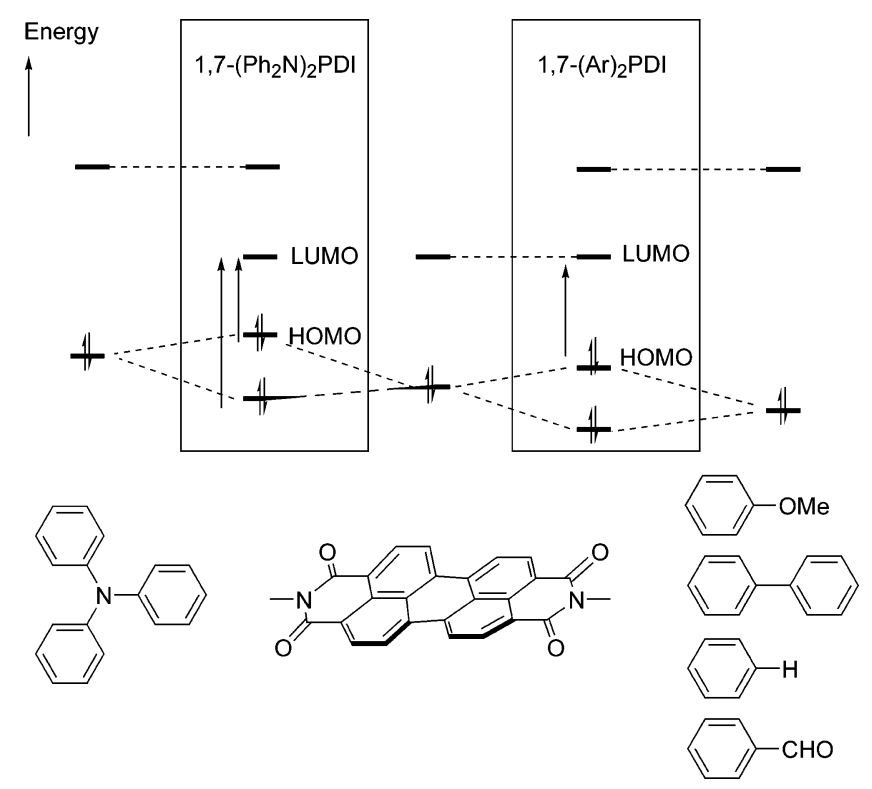

TABLE 4. Oxidation and Reduction $E_{1 / 2}$ Potentials $^{a}$ for 1,7-Ar ${ }_{2}$ PDIs

\begin{tabular}{|c|c|c|c|c|c|}
\hline \multirow[b]{2}{*}{ PDIs } & \multicolumn{2}{|c|}{ oxidation $^{b}$} & \multicolumn{3}{|c|}{ reduction } \\
\hline & 2nd & 1 st & 1st & 2nd & $3 r d^{b}$ \\
\hline $4-(\mathrm{OCH}) \mathrm{C}_{6} \mathrm{H}_{4}$ & & +1.83 & -0.32 & -0.54 & -1.88 \\
\hline $\mathrm{Br}$ & & & -0.36 & -0.56 & -2.0 \\
\hline $2,4,6-(\mathrm{Me})_{3} \mathrm{C}_{6} \mathrm{H}_{2}$ & & & -0.39 & -0.64 & \\
\hline $4-(\mathrm{MeO}) \mathrm{C}_{6} \mathrm{H}_{4}$ & & +1.54 & -0.42 & -0.65 & \\
\hline $4-\left(\mathrm{Ph}_{2} \mathrm{~N}\right) \mathrm{C}_{6} \mathrm{H}_{4}$ & & +1.13 & -0.44 & -0.64 & \\
\hline $\mathrm{C}_{6} \mathrm{H}_{5}$ & & +1.70 & -0.44 & -0.64 & \\
\hline 4-(Ph) $\mathrm{C}_{6} \mathrm{H}_{4}$ & & +1.65 & -0.48 & -0.74 & \\
\hline 1-naphthyl & & +1.75 & -0.50 & -0.77 & \\
\hline $2,5-(\mathrm{MeO})_{2} \mathrm{C}_{6} \mathrm{H}_{3}$ & +1.60 & +1.43 & -0.54 & -0.79 & \\
\hline $2,4-(\mathrm{MeO})_{2} \mathrm{C}_{6} \mathrm{H}_{3}$ & & +1.53 & -0.57 & -0.82 & \\
\hline
\end{tabular}

the PDI LUMO would lead to some charge-transfer character from the aryl side groups to the PDI core.

On the other hand, the HOMO of the $\mathrm{Ph}_{2} \mathrm{NC}_{6} \mathrm{H}_{4}$ group was found to be $1 \mathrm{eV}$ above the core HOMO. Orbital interactions would lower the energy level of the PDI HOMO and raise the energy level of the $\mathrm{Ph}_{2} \mathrm{NC}_{6} \mathrm{H}_{4}$ group's HOMO. Therefore, the HOMO of $4 \mathbf{i}$ mainly originates from the HOMO of the $\mathrm{Ph}_{2} \mathrm{NC}_{6} \mathrm{H}_{4}$ units. The absorption band at $653 \mathrm{~nm}$ is assigned to the chargetransfer absorption, involving the electronic transition from the HOMO of the $\mathrm{Ph}_{2} \mathrm{NC}_{4} \mathrm{H}_{4}$ group to the LUMO of PDI. On the other hand, the blue-shifted absorption maximum at $512 \mathrm{~nm}$ was assigned to the electronic transition from the PDI HOMO to the PDI LUMO.

To further confirm our theoretical conclusions, we employed cyclic voltammetry to evaluate the substituent effects on the HOMO and LUMO of the perylene core. The experiments were carried out in $\mathrm{CH}_{3} \mathrm{CN}$ or in a mixed solvent of $\mathrm{CH}_{3} \mathrm{CN}$ and $\mathrm{CH}_{2} \mathrm{Cl}_{2}$ (1:1) in the presence of $\mathrm{Bu}_{4} \mathrm{NClO}_{4}$ as the supporting electrolyte. Their redox $E_{1 / 2}$ values and reversibility are summarized in Table 4 .

To avoid interference from steric factors, we again selected a series of para-substituted derivatives, including the 4-CHO-, 4-H-, 4-Ph-, 4-MeO-, and $4-\mathrm{Ph}_{2} \mathrm{~N}$ substituted $\mathrm{Ph}_{2} \mathrm{PDI} \mathbf{4 c}, \mathbf{4 d}, \mathbf{4 e}, \mathbf{4 f}$, and $\mathbf{4 i}$, respectively, 


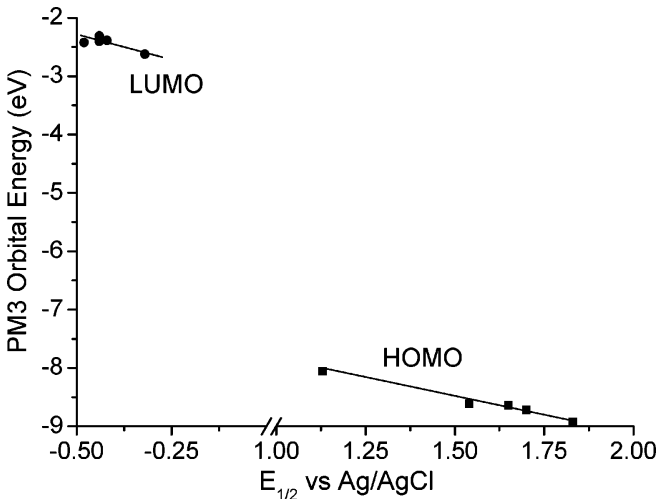

FIGURE 7. Correlation plots of the PM3 HOMO and LUMO energies versus the oxidation and the first reduction $E_{1 / 2}$ values from the CV experiments.

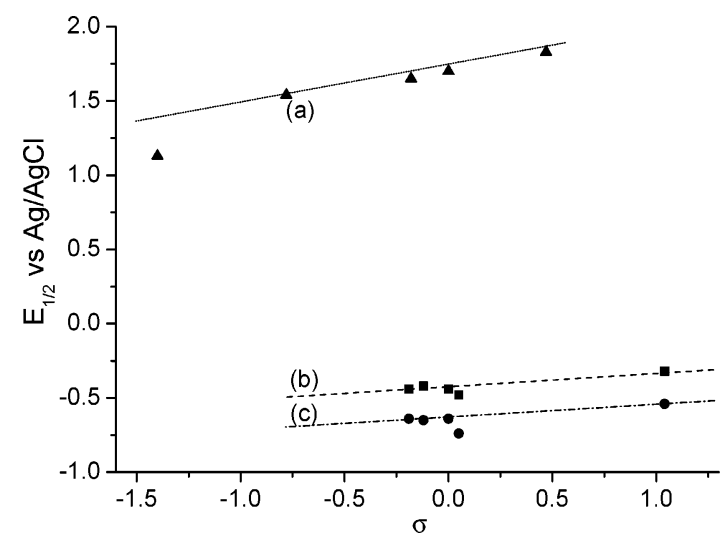

FIGURE 8. Hammett plot of $E_{1 / 2}$ (vs $\mathrm{Ag} / \mathrm{AgCl}$ ) versus $\sigma$ for phenyl-substituted PDIs $\mathbf{4 c}-\mathbf{4 f}$ and $\mathbf{4 i}$ : (a) the first oxidation wave, (b) the first reduction wave, and (c) the second reduction wave. The $\sigma^{+}$values were used for $\mathrm{Ph}_{2} \mathrm{~N}, \mathrm{MeO}$, and $\mathrm{Ph}$ groups in the oxidation plot. The $\sigma^{-}$value was used for $\mathrm{CHO}$ in the reduction plots.

for comparison. Most of the PDIs show one oxidation wave and two reduction waves, similar to the results reported in the literature. ${ }^{18}$ Figure 7 shows the correlation plots of the orbital energies versus the $E_{1 / 2}$ values of the redox waves in the $\mathrm{CV}$ experiments. Reasonably good linear correlations in both plots support the validity of the above theoretical analysis.

Figure 8 shows the Hammett plots of the $E_{1 / 2}$ (vs Ag/ $\mathrm{AgCl}$ ) versus $\sigma$ for phenyl-substituted PDIs $\mathbf{4 c}-\mathbf{4 f}$ and 4i. Substituent electronic effects are clearly observed on the oxidation waves of substituted PDIs. A progressive shift of the first oxidation potential to a low value was observed when the electron-donating ability of the substituents was increased. The difference between the oxidative $E_{1 / 2}$ values of $4 \mathbf{e}$ and $4 \mathbf{f}$ is $0.29 \mathrm{~V}$. A good Hammett correlation of $1 / \lambda_{\max }$ versus $\sigma^{+}$was observed for the first four derivatives with a slope of $\rho_{\text {abs }}=230 \mathrm{mV}$. The correlation coefficient is 0.99 . The linearity of the plot against $\sigma^{+}$with the positive slope suggested that the partial positive charge would be delocalized onto the phenyl side chains. On the other hand, the $E_{1 / 2}$ of $4 \mathbf{i}$ is

(18) (a) Lee, S. K.; Zu, Y.; Herrmann, A.; Geerts, Y.; Müllen, K.; Bard, A. J. J. Am. Chem. Soc. 1999, 121, 3513-3520. (b) Lu, W.; Gao, J. P.; Wang, Z. Y.; Qi, Y.; Sacripante, G. G.; Duff, J. D.; Sundararajan, P. R. Macromolecules 1999, 32, 8880-8885. unusually low and away from the regression line. This observation is in good agreement with our theoretical prediction as well as the absorptive spectral data. It is noteworthy to remember that the $\mathrm{C}_{6} \mathrm{H}_{4} \mathrm{NPh}_{2}$ units contain a high-lying HOMO. Therefore, the $\mathrm{C}_{6} \mathrm{H}_{4} \mathrm{NPh}_{2}$ unit should have major contribution to the HOMO of $\mathbf{4 i}$. Electrochemical oxidation would, therefore, occur on the $\mathrm{C}_{6} \mathrm{H}_{4} \mathrm{NPh}_{2}$ units at particularly low oxidation potentials that do not follow the trend of the Hammett plot.

Although one may consider the dimethoxy-substituted phenyl groups as electron-rich substituents, the introduction of methoxy groups at the ortho position sterically restricts the phenyl ring orthogonally to the perylene core and hence partially offsets the electron-donating power of the methoxy substituents. Therefore, the difference of redox potentials of 4-( $\mathrm{MeO}) \mathrm{C}_{6} \mathrm{H}_{4^{-}}, 2,5-(\mathrm{MeO})_{2} \mathrm{C}_{6} \mathrm{H}_{2^{-}}$, and 2,4-( $\mathrm{MeO})_{2} \mathrm{C}_{6} \mathrm{H}_{2}$-substituted PDIs $\mathbf{4} \mathbf{f}-\mathbf{4 h}$ is small.

On the the other hand, the variation of the reductive half potentials of $\mathrm{C}_{6} \mathrm{H}_{5^{-}}, 4-(\mathrm{Ph}) \mathrm{C}_{6} \mathrm{H}_{4^{-}}, 4-(\mathrm{MeO}) \mathrm{C}_{6} \mathrm{H}_{4^{-}}$, and 4- $\left(\mathrm{Ph}_{2} \mathrm{~N}\right) \mathrm{C}_{6} \mathrm{H}_{4}$-substituted PDIs is $0.06 \mathrm{~V}$, a relatively small value. Even the difference of the reductive $E_{1 / 2}$ between $4 \mathbf{e}$ and $4 \mathbf{f}$ is only around $0.1 \mathrm{~V}$. The slope of the Hammett plot was found to be $104 \mathrm{mV}$ with a correlation coefficient of 0.87. A similar situation occurs on the second reduction wave, indicating that the substituent effects on the reduction potentials are small. The slope of the Hammett plot was found to be $100 \mathrm{mV}$ with a correlation coefficient of 0.71 . These results are in good agreement with our theoretical prediction in which the perturbation effects on the LUMO by substituents are less.

In summary, we reported the salient substituent effects on the photophysical and electrochemical properties of the PDI core. PDI molecule 4i has unusual dual-band absorption that spans from 450 to $750 \mathrm{~nm}$. Application of these molecules for solar cells and optoelectronics is under investigation.

\section{Experimental Section}

Materials. Compound 2, $\mathrm{Pd}\left(\mathrm{PPh}_{3}\right)_{4}$, and $\mathrm{Na}_{2} \mathrm{CO}_{3}$ were purchased from a commercial supplier. All other reagents and solvents were of analytical or chemical grade and were purified using standard methods.

Procedure for the UV-Vis Absorption and Fluorescence Measurements. UV-vis and fluorescence spectra were collected between 200 and $900 \mathrm{~nm}$ for the compounds in $\mathrm{CHCl}_{3}$. The quantum yields were measured by comparison against $\mathbf{1}$ as the standard. Compound $\mathbf{1}$ is known to have a quantum yield of $1 .{ }^{10 \mathrm{c}}$

Procedures for Cyclic Voltammetric (CV) Measurements. Electrochemical oxidation and reduction behavior of $4 \mathbf{a}-4 \mathbf{i}$ were measured by $\mathrm{CV}(0-1.5 \mathrm{~V}, 100 \mathrm{mV} / \mathrm{s})$ in $\mathrm{CH}_{3} \mathrm{CN}$ or $\mathrm{CH}_{3} \mathrm{CN} / \mathrm{CH}_{2} \mathrm{Cl}_{2}(1: 1)$ using $\mathrm{Bu}_{4} \mathrm{NClO}_{4}(0.1 \mathrm{M})$ or $\mathrm{Bu}_{4} \mathrm{NPF}_{6}$ $(0.1 \mathrm{M})$ as the supporting electrolyte. The signals were obtained on a glassy-carbon working electrode with a Pt wire as the counter electrode and a $\mathrm{Ag} / \mathrm{AgCl}$ (saturated) electrode as the reference electrode.

Methods for Theoretical Calculations. Semiempirical calculations were carried out by employing MM2 (Chem 3D) for structural optimization and PM3 (Cauche Company) for orbital analysis.

$N, N^{\prime}$-Bis(2,6-diisopropylphenyl)-1,7-dibromoperylene3,4,9,10-tetracarboxydiimide (3). ${ }^{19}$ Perylene- $3,4,9,10$-tetracarboxylic dianhydride $2(32.0 \mathrm{~g}, 81.4 \mathrm{mmol})$, iodine $(0.77 \mathrm{~g}$, $3.03 \mathrm{mmol})$, and sulfuric acid $(98 \%, 450 \mathrm{~mL})$ were premixed and stirred for $2 \mathrm{~h}$ at room temperature. The reaction tem- 
perature was set at $80{ }^{\circ} \mathrm{C}$, and bromine $(9.2 \mathrm{~mL}, 180 \mathrm{mmol})$ was added dropwise over $2 \mathrm{~h}$. The mixture was reacted further at $80{ }^{\circ} \mathrm{C}$ for $16 \mathrm{~h}$. The reaction mixture was cooled to room temperature, and the excess $\mathrm{Br}_{2}$ was displaced by nitrogen. The product was precipitated by addition of ice-water and collected by suction filtration. The precipitate was washed with water several times until the aqueous layer became neutral to yield dibromo dianhydride as a crude product. The crude product was then dried under reduced pressure at $120^{\circ} \mathrm{C}$ and used for the next step without further purification.

The crude 1,7-dibromoperylene-3,4,9,10-tetracarboxylic dianhydride ( $80 \mathrm{~g}, 14.5 \mathrm{mmol}$ ), excess 2,6 -diisopropylaniline ( 88 $\mathrm{mL}, 46.7 \mathrm{mmol})$, and acetic acid $(46 \mathrm{~mL})$ were mixed and heated at $120^{\circ} \mathrm{C}$ in NMP ( $\left.1 \mathrm{~L}\right)$ under a nitrogen atmosphere for $120 \mathrm{~h}$. The product was precipitated by the addition of water and collected by suction filtration. The crude product was washed with water until neutral and dried. The crude product was first purified by column chromatography on silica gel using $\mathrm{CH}_{2} \mathrm{Cl}_{2}$ as the eluent to obtain a mixture of the isomeric diimides. The mixture was washed with $\mathrm{EtOH}$ (300 $\mathrm{mL})$ and toluene $(300 \mathrm{~mL})$ and then heated at $80^{\circ} \mathrm{C}$ in toluene $(300 \mathrm{~mL})$ for $12 \mathrm{~h}$. The pure diimide was recrystallized from the hot toluene solution. The crystals were collected through hot filtration to provide an essentially pure orange compound, 3 (46 g, $36 \%$ overall yield): ${ }^{1} \mathrm{H}$ NMR $\left(400 \mathrm{MHz}, \mathrm{CDCl}_{3}\right) \delta 9.56$ $(\mathrm{d}, J=8.0 \mathrm{~Hz}, 2 \mathrm{H}), 9.01(\mathrm{~s}, 2 \mathrm{H}), 8.79(\mathrm{~d}, J=8.0 \mathrm{~Hz}, 2 \mathrm{H})$, $7.50(\mathrm{t}, J=8.0 \mathrm{~Hz}, 2 \mathrm{H}), 7.35(\mathrm{~d}, J=8.0 \mathrm{~Hz}, 4 \mathrm{H}), 2.73$ (septet, $J=6.8 \mathrm{~Hz}, 4 \mathrm{H}), 1.18(\mathrm{~d}, J=6.8 \mathrm{~Hz}, 24 \mathrm{H}) ;{ }^{13} \mathrm{C} \mathrm{NMR}(100 \mathrm{MHz}$, $\left.\mathrm{CDCl}_{3}\right) \delta 162.8,162.3,145.4,138.3,133.3,133.1,130.5,129.96$, $129.75,129.48,128.8,127.5,124.1,123.1,122.7,120.9,29.4$, $24.1,24.1$; HRFAB $m / z$ 869.1422, calcd for $\mathrm{C}_{48} \mathrm{H}_{40} \mathrm{Br}_{2} \mathrm{~N}_{2} \mathrm{O}_{4} \mathrm{~m} / z$ 866.1355 .

A General Procedure for the Preparation of 1,7$\mathrm{Ar}_{2}$ PDI. $N, N^{\prime}$-Bis(2,6-diisopropylphenyl)-1,7-bis(2,4,6-trimethylphenyl)perylene-3,4,9,10-tetracarboxydiimide (4a). A deaerated mixture of EtOH $(8.2 \mathrm{~mL})$, benzene $(47 \mathrm{~mL})$, and $\mathrm{H}_{2} \mathrm{O}(23 \mathrm{~mL})$ was added to a solid mixture of $3(7.0 \mathrm{~g}, 8.1$ $\mathrm{mmol}), 2,4,6$-trimethylphenylboronic acid ${ }^{20}(10.6 \mathrm{~g}, 64.6 \mathrm{mmol})$, $\mathrm{Pd}\left(\mathrm{PPh}_{3}\right)_{4}$ (466 mg, $5.0 \mathrm{~mol} \%$ ), and $\mathrm{Na}_{2} \mathrm{CO}_{3}(2.56 \mathrm{~g}, 24.2 \mathrm{mmol})$ under nitrogen. The mixture was reacted at $80^{\circ} \mathrm{C}$ for $120 \mathrm{~h}$. The reaction was quenched by the addition of water. The mixture was extracted with $\mathrm{CH}_{2} \mathrm{Cl}_{2}$ several times. The combined organic layer was dried over anhydrous $\mathrm{MgSO}_{4}$ and concentrated under reduced pressure to provide a crude solid. The crude solid was further purified by column chromatography on silica gel using toluene $/ \mathrm{CH}_{2} \mathrm{Cl}_{2}(1: 1)$ as the eluent to obtain 4a as an orange red solid (5.5 g, 72\%): $\mathrm{mp}>380^{\circ} \mathrm{C}$ dec; ${ }^{1} \mathrm{H}$ NMR $\left(400 \mathrm{MHz}, \mathrm{CDCl}_{3}\right) \delta 8.44(\mathrm{~s}, 2 \mathrm{H}), 8.30(\mathrm{~d}, J=8.0$ $\mathrm{Hz}, 2 \mathrm{H}), 8.12(\mathrm{~d}, J=8.0 \mathrm{~Hz}, 2 \mathrm{H}), 7.47(\mathrm{t}, J=7.6 \mathrm{~Hz}, 2 \mathrm{H})$, $7.32(\mathrm{~d}, J=7.6 \mathrm{~Hz}, 4 \mathrm{H}), 7.09(\mathrm{~s}, 4 \mathrm{H}), 2.74$ (septet, $J=6.4 \mathrm{~Hz}$, $4 \mathrm{H}), 2.42(\mathrm{~s}, 6 \mathrm{H}), 2.03(\mathrm{~s}, 12 \mathrm{H}), 1.15(\mathrm{~d}, J=6.4 \mathrm{~Hz}, 24 \mathrm{H}) ;{ }^{13} \mathrm{C}$ NMR $\left(100 \mathrm{MHz}^{\left.-\mathrm{CDCl}_{3}\right)} \delta 163.4,163.1,145.5,139.6,138.8\right.$, $138.23,136.1,135.9,134.0,133.2,130.9,130.3,130.0,129.6$, 128.5, 128.5, 127.0, 124.0, 122.6, 122.2, 29.3, 24.2, 21.4, 20.9; HRFAB m/z 947.4796, calcd for $\mathrm{C}_{66} \mathrm{H}_{62} \mathrm{~N}_{2} \mathrm{O}_{4} \mathrm{~m} / z$ 946.4710. Anal. Calcd for $\mathrm{C}_{66} \mathrm{H}_{62} \mathrm{~N}_{2} \mathrm{O}_{4}$ : C, 83.69; H, 6.60; N, 2.96 . Found: C, 83.79; H, 6.42; N, 2.89

syn- and anti- $N, N^{\prime}$-Bis(2,6-diisopropylphenyl)-1,7-dinaphth-1-ylperylene-3,4,9,10-tetracarboxydiimide (4b). The reaction of $\mathbf{3}(3.0 \mathrm{~g}, 3.5 \mathrm{mmol})$, 1-naphthaleneboronic $\mathrm{acid}^{21}$ (4.76 g, $27.7 \mathrm{mmol}), \mathrm{Pd}\left(\mathrm{PPh}_{3}\right)_{4}(100 \mathrm{mg}, 2.5 \mathrm{~mol} \%)$, and $\mathrm{Na}_{2} \mathrm{CO}_{3}(1.10 \mathrm{~g}, 10.4 \mathrm{mmol})$ in degassed EtOH $(3.5 \mathrm{~mL})$, benzene $(20 \mathrm{~mL})$, and $\mathrm{H}_{2} \mathrm{O}(10 \mathrm{~mL})$ under nitrogen at $80{ }^{\circ} \mathrm{C}$ for $12 \mathrm{~h}$ followed by column chromatography purification on silica gel using toluene/ $\mathrm{CH}_{2} \mathrm{Cl}_{2}$ (1:1) as the eluent produced 4b (two conformational isomers, 1:1 ratio) as a red solid (2.7 g, 84\%): $\mathrm{mp}>390{ }^{\circ} \mathrm{C} \mathrm{dec} ;{ }^{1} \mathrm{H} \mathrm{NMR}\left(400 \mathrm{MHz}, \mathrm{CDCl}_{3}\right) \delta 8.69$, 8.67 (two conformers (1:1), s, $2 \mathrm{H}), 8.06-8.00(\mathrm{~m}, 6 \mathrm{H}), 7.93-$

(19) Hofkens, J.; Vosch, T.; Maus, M.; Kohn, F.; Cotlet, M.; Weil, T.; Herrmann, A.; Müllen, K.; De Schryver, F. C. Chem. Phys. Lett. 2001, 333, 255-263.

(20) Wipf, P.; Jung, J.-K. J. Org. Chem. 2000, 65, 6319-6337. $7.90(\mathrm{~m}, 2 \mathrm{H}), 7.85(\mathrm{~d}, J=8 \mathrm{~Hz}, 1 \mathrm{H}), 7.79(\mathrm{~d}, J=8.0 \mathrm{~Hz}, 1 \mathrm{H})$, $7.69-7.39(\mathrm{~m}, 10 \mathrm{H}), 7.28(\mathrm{~d}, J=7.6 \mathrm{~Hz}, 4 \mathrm{H}), 2.73-2.66(\mathrm{~m}$, $4 \mathrm{H}), 1.15-1.07(\mathrm{~m}, 24 \mathrm{H}) ;{ }^{13} \mathrm{C} \mathrm{NMR}\left(100 \mathrm{MHz}, \mathrm{CDCl}_{3}\right) \delta 163.2$, $163.1,145.5,145.4,140.1,140.0,139.4,139.2,136.7,136.6$, $135.3,135.2,134.4,134.3,134.1,134.0,130.7,130.5,130.4$, $130.3,130.2,129.5,129.4,129.2,129.04,128.97,128.9,128.6$, $128.5,127.5,127.3,127.1,126.8,126.72,126.67,126.44$, $126.37,124.7,124.6,123.9,122.2,122.0,29.24,29.22,24.15$, 24.10; $\mathrm{HRFAB} \mathrm{m} / z$ 963.4158, calcd for $\mathrm{C}_{68} \mathrm{H}_{54} \mathrm{~N}_{2} \mathrm{O}_{4} \mathrm{~m} / \mathrm{z} 962.4084$. Anal. Calcd for $\mathrm{C}_{68} \mathrm{H}_{54} \mathrm{~N}_{2} \mathrm{O}_{4}$ : C, 84.80; H, 5.65; N, 2.91 . Found: C, 85.05; H, 5.75; N, 2.76.

$\boldsymbol{N}, \boldsymbol{N}^{\prime}$-Bis(2,6-diisopropylphenyl)-1,7-diphenylperylene$\mathbf{3 , 4 , 9 , 1 0 - t e t r a c a r b o x y d i i m i d e ~ ( 4 c )}$. The reaction of $\mathbf{3}(3.0 \mathrm{~g}$, $3.5 \mathrm{mmol})$, phenylboronic acid ${ }^{22}(3.38 \mathrm{~g}, 27.7 \mathrm{mmol}), \mathrm{Pd}\left(\mathrm{PPh}_{3}\right)_{4}$ (100 mg, $2.5 \mathrm{~mol} \%$ ), and $\mathrm{Na}_{2} \mathrm{CO}_{3}(1.10 \mathrm{~g}, 10.4 \mathrm{mmol})$ in degassed EtOH $(3.5 \mathrm{~mL})$, benzene $(20 \mathrm{~mL})$, and $\mathrm{H}_{2} \mathrm{O}(10 \mathrm{~mL})$ at $80{ }^{\circ} \mathrm{C}$ for $8 \mathrm{~h}$ followed by column chromatographic purification on silica gel using toluene/ $\mathrm{CH}_{2} \mathrm{Cl}_{2}(1: 1)$ as the eluent produced 4c as a red solid $(2.7 \mathrm{~g}, 90 \%): \mathrm{mp}>390{ }^{\circ} \mathrm{C} \mathrm{dec} ;{ }^{1} \mathrm{H}$ NMR $\left(400 \mathrm{MHz} \mathrm{CDCl}_{3}\right) \delta 8.71(\mathrm{~s}, 2 \mathrm{H}), 8.20(\mathrm{~d}, J=8.0 \mathrm{~Hz}$, $2 \mathrm{H}), 7.92(\mathrm{~d}, J=8.0 \mathrm{~Hz}, 2 \mathrm{H}), 7.62(\mathrm{dd}, J=8.0,1.6 \mathrm{~Hz}, 4 \mathrm{H})$, $7.53-7.45(\mathrm{~m}, 8 \mathrm{H}), 7.32(\mathrm{~d}, J=8.0 \mathrm{~Hz}, 4 \mathrm{H}), 2.74$ (septet, $J=$ $6.8 \mathrm{~Hz}, 4 \mathrm{H}), 1.15(\mathrm{~m}, 24 \mathrm{H}) ;{ }^{13} \mathrm{C}$ NMR $\left(100 \mathrm{MHz}, \mathrm{CDCl}_{3}\right) \delta$ $163.27,163.24,145.4,141.9,141.27,135.7,135.2,132.9,130.4$, $130.3,130.2,129.9,129.5,129.5,128.9,128.7,128.3,124.0$, $122.2,121.8,29.3,24.2,24.1$; HRFAB $\mathrm{m} / z$ 863.3862, calcd for $m / z \mathrm{C}_{60} \mathrm{H}_{50} \mathrm{~N}_{2} \mathrm{O}_{4}$ 862.3771. Anal. Calcd for $\mathrm{C}_{60} \mathrm{H}_{50} \mathrm{~N}_{2} \mathrm{O}_{4}$ : C, 83.50; H, 5.84; N, 3.25. Found: C, 83.54; H, 5.63; N, 3.17.

$N, N^{\prime}$-Bis(2,6-diisopropylphenyl)-1,7-bis(biphenyl-4-yl)perylene-3,4,9,10-tetracarboxydiimide (4d). The reaction of $3(3.0 \mathrm{~g}, 3.5 \mathrm{mmol})$, biphenyl-4-boronic acid $^{23}$ (5.48 g, 27.7 $\mathrm{mmol}), \mathrm{Pd}\left(\mathrm{PPh}_{3}\right)_{4}(100 \mathrm{mg}, 2.5 \mathrm{~mol} \%)$, and $\mathrm{Na}_{2} \mathrm{CO}_{3}(1.10 \mathrm{~g}$, $10.4 \mathrm{mmol})$ in degassed EtOH $(3.5 \mathrm{~mL})$, benzene $(20 \mathrm{~mL})$, and $\mathrm{H}_{2} \mathrm{O}(10 \mathrm{~mL})$ under nitrogen at $80{ }^{\circ} \mathrm{C}$ for $12 \mathrm{~h}$ followed by column chromatographic purification on silica gel using toluene/ $\mathrm{CH}_{2} \mathrm{Cl}_{2}$ (1:1) as the eluent produced $\mathbf{4 d}$ as a red solid $(91 \%$, $3.2 \mathrm{~g}): \mathrm{mp}>390{ }^{\circ} \mathrm{C} \mathrm{dec} ;{ }^{1} \mathrm{H}$ NMR $\left(400 \mathrm{MHz}, \mathrm{CDCl}_{3}\right) \delta 8.76$ $(\mathrm{s}, 2 \mathrm{H}), 8.24(\mathrm{~d}, J=8.0 \mathrm{~Hz}, 2 \mathrm{H}), 8.09(\mathrm{~d}, J=8.0 \mathrm{~Hz}, 2 \mathrm{H})$, $7.79-7.70(\mathrm{~m}, 12 \mathrm{H}), 7.51-7.45(\mathrm{~m}, 6 \mathrm{H}), 7.40(\mathrm{t}, J=8.0 \mathrm{~Hz}$, $2 \mathrm{H}), 7.33(\mathrm{~d}, J=8.0 \mathrm{~Hz}, 4 \mathrm{H}), 2.76$ (septet, $J=6.8 \mathrm{~Hz}, 4 \mathrm{H}$ ), $1.81-1.15(\mathrm{~m}, 24 \mathrm{H}) ;{ }^{13} \mathrm{C} \mathrm{NMR}\left(100 \mathrm{MHz}, \mathrm{CDCl}_{3}\right) \delta 163.3,163.2$, $145.4,141.5,140.9,140.8,139.8,135.8,135.3,132.9,130.4$, $130.3,123.0,129.6,129.54,129.47,128.9,128.8,128.3,127.8$, $127.0,124.0,122.3,121.9,29.3,24.2,24.1$; HRFAB $\mathrm{m} / \mathrm{z}$ 1015.4472, calcd for $\mathrm{C}_{72} \mathrm{H}_{58} \mathrm{~N}_{2} \mathrm{O}_{4} \mathrm{~m} / z$ 1014.4397. Anal. Calcd for $\mathrm{C}_{60} \mathrm{H}_{50} \mathrm{~N}_{2} \mathrm{O}_{4}$ : C, 85.18; H, 5.78; N, 2.76. Found: C, 85.04; $\mathrm{H}, 5.78 ; \mathrm{N}, 2.89$.

$N, N^{\prime}$-Bis(2,6-diisopropylphenyl)-1,7-di(4-formylphenyl)perylene-3,4,9,10-tetracarboxydiimide $(4 \mathrm{e})$. The reaction of $3(3.0 \mathrm{~g}, 3.5 \mathrm{mmol})$, 4-formylphenylboronic $\operatorname{acid}^{24}(4.15 \mathrm{~g}$, $27.7 \mathrm{mmol}), \mathrm{Pd}\left(\mathrm{PPh}_{3}\right)_{4}(100 \mathrm{mg}, 2.5 \mathrm{~mol} \%)$, and $\mathrm{Na}_{2} \mathrm{CO}_{3}(1.10$ $\mathrm{g}, 10.4 \mathrm{mmol})$ in degassed EtOH $(3.5 \mathrm{~mL})$, benzene $(20 \mathrm{~mL})$ and, $\mathrm{H}_{2} \mathrm{O}(10 \mathrm{~mL})$ under nitrogen at $80{ }^{\circ} \mathrm{C}$ for $96 \mathrm{~h}$ followed by column chromatographic purification on silica gel using $\mathrm{CH}_{2} \mathrm{Cl}_{2}$ as the eluent produced $4 \mathbf{e}$ as a red solid $(2.3 \mathrm{~g}, 72 \%)$ : $\mathrm{mp}>380{ }^{\circ} \mathrm{C} \mathrm{dec} ;{ }^{1} \mathrm{H}$ NMR $\left(400 \mathrm{MHz}, \mathrm{CDCl}_{3}\right) \delta 10.14(\mathrm{~s}, 2 \mathrm{H})$, $8.72(\mathrm{~s}, 2 \mathrm{H}), 8.24(\mathrm{~d}, J=8.4 \mathrm{~Hz}, 2 \mathrm{H}), 8.07(\mathrm{~d}, J=8.4 \mathrm{~Hz}, 4 \mathrm{H})$, $7.85(\mathrm{t}, J=8.4 \mathrm{~Hz}, 6 \mathrm{H}), 7.48(\mathrm{t}, J=7.6 \mathrm{~Hz}, 2 \mathrm{H}), 7.34(\mathrm{~d}, J=$ $7.6 \mathrm{~Hz}, 4 \mathrm{H}), 2.73$ (septet, $J=6.8 \mathrm{~Hz}, 4 \mathrm{H}), 1.20-1.15(\mathrm{~m}, 24 \mathrm{H})$; ${ }^{13} \mathrm{C}$ NMR $\left(100 \mathrm{MHz}, \mathrm{CDCl}_{3}\right) \delta 191.1,163.0,162.9,147.8,145.4$, $139.9,136.0,135.2,134.6,132.9,131.4,130.8,130.2,130.1$, $129.9,129.7,129.3,128.5,124.0,122.6,122.3,29.3,24.2,24.1$; HRFAB $m / z$ 919.3757, calcd for $m / z \mathrm{C}_{62} \mathrm{H}_{50} \mathrm{~N}_{2} \mathrm{O}_{6} 918.3669$. Anal. Calcd for $\mathrm{C}_{62} \mathrm{H}_{50} \mathrm{~N}_{2} \mathrm{O}_{6}$ : C, 81.02; H, 5.48; N, 3.05. Found: C, 80.80; H, 5.56; N, 2.85.

(21) Faraoni, M. B.; Koll, L. C.; Mandolesi, S. D.; Zúòiga, A. E.; Podestá, J. C. J. Organomet. Chem. 2000, 613, 236-238.

(22) Seaman, W.; Johnson, J. R. J. Am. Chem. Soc. 1931, 53, 711723.

(23) Ishida, T.; Mizutani, W.; Choi, N.; Akiba, U.; Fujihira, M.; Tokumoto, H. J. Phys. Chem. B 2000, 104, 11680-11688

(24) Park, K. C.; Yoshino, K.; Tomiyasu, H. Synthesis 1999, 12, 2041-2044. 
$N, N^{\prime}$-Bis(2,6-diisopropylphenyl)-1,7-bis(4-methoxyphenyl)perylene-3,4,9,10-tetracarboxydiimide (4f). The reaction of 3 (3.0 g, $3.5 \mathrm{mmol})$, 4-methoxyphenylboronic acid ${ }^{25}(4.21$ g, $27.7 \mathrm{mmol}), \mathrm{Pd}\left(\mathrm{PPh}_{3}\right)_{4}(100 \mathrm{mg}, 2.5 \mathrm{~mol} \%)$, and $\mathrm{Na}_{2} \mathrm{CO}_{3}$ $(1.10 \mathrm{~g}, 10.4 \mathrm{mmol})$ in degassed $\mathrm{EtOH}(3.5 \mathrm{~mL})$, benzene $(20$ $\mathrm{mL})$, and $\mathrm{H}_{2} \mathrm{O}(10 \mathrm{~mL})$ under nitrogen at $80^{\circ} \mathrm{C}$ for $8 \mathrm{~h}$ followed by column chromatographic purification on silica gel using toluene/ $\mathrm{CH}_{2} \mathrm{Cl}_{2}(2: 3)$ as the eluent produced $\mathbf{4 f}$ as a red solid $(2.1 \mathrm{~g}, 66 \%): \mathrm{mp}>380{ }^{\circ} \mathrm{C} \mathrm{dec} ;{ }^{1} \mathrm{H}$ NMR $\left(400 \mathrm{MHz}, \mathrm{CDCl}_{3}\right) \delta$ $8.69(\mathrm{~s}, 2 \mathrm{H}), 8.22(\mathrm{~d}, J=8.0 \mathrm{~Hz}, 2 \mathrm{H}), 7.99(\mathrm{~d}, J=8.0 \mathrm{~Hz}, 2 \mathrm{H})$, $7.54(\mathrm{~d}, J=8.4 \mathrm{~Hz}, 4 \mathrm{H}), 7.47(\mathrm{t}, J=8.0 \mathrm{~Hz}, 2 \mathrm{H}), 7.32(\mathrm{~d}, J=$ $8.0 \mathrm{~Hz}, 4 \mathrm{H}), 7.02(\mathrm{~d}, J=8.4 \mathrm{~Hz}, 4 \mathrm{H}), 3.91(\mathrm{~s}, 6 \mathrm{H}), 2.74$ (septet, $J=6.8 \mathrm{~Hz}, 4 \mathrm{H}), 1.17-1.14(\mathrm{~m}, 24 \mathrm{H}) ;{ }^{13} \mathrm{C} \mathrm{NMR}(100 \mathrm{MHz}$, $\left.\mathrm{CDCl}_{3}\right) \delta 163.4,163.3,160.0,145.4,140.9,135.8,135.5,134.2$, $132.8,130.4,130.3,129.8,129.7,129.7,129.5,128.2,124.0$, $122.1,121.6,115.6,55.5,29.3,24.2,24.1$; HRFAB $\mathrm{m} / \mathrm{z}$ 923.4080, calcd for $\mathrm{C}_{62} \mathrm{H}_{54} \mathrm{~N}_{2} \mathrm{O}_{6} \mathrm{~m} / z$ 922.3982. Anal. Calcd for $\mathrm{C}_{62} \mathrm{H}_{54} \mathrm{~N}_{2} \mathrm{O}_{6}$ : C, 80.67; H, 5.90; N, 3.03. Found: C, 80.49; H, $5.92 ; \mathrm{N}, 2.99$.

syn- and anti- $N, N^{\prime}$-Bis(2,6-diisopropylphenyl)-1,7-bis(2,4-dimethoxyphenyl)perylene-3,4,9,10-tetracarboxydiimide (4g). The reaction of $3(4.0 \mathrm{~g}, 4.6 \mathrm{mmol})$, 2,4dimethoxyphenylboronic acid ${ }^{26}$ (5.04 g, $\left.27.7 \mathrm{mmol}\right), \mathrm{Pd}\left(\mathrm{PPh}_{3}\right)_{4}$ (133 mg, $2.5 \mathrm{~mol} \%$ ), and $\mathrm{Na}_{2} \mathrm{CO}_{3}(1.47 \mathrm{~g}, 13.5 \mathrm{mmol})$ in degassed $\mathrm{EtOH}(4.7 \mathrm{~mL})$, benzene $(26.6 \mathrm{~mL})$, and $\mathrm{H}_{2} \mathrm{O}(13.3$ $\mathrm{mL}$ ) under nitrogen at $80{ }^{\circ} \mathrm{C}$ for $16 \mathrm{~h}$ followed by column chromatographic purification on silica gel using toluene/ $\mathrm{CH}_{2} \mathrm{Cl}_{2}$ (2:3) as the eluent produced $\mathbf{4 g}$ (two conformational isomers, 1:1 ratio) as a red solid $(3.2 \mathrm{~g}, 70 \%): \mathrm{mp}>360{ }^{\circ} \mathrm{C}$ dec; ${ }^{1} \mathrm{H}$ NMR $\left(400 \mathrm{MHz}, \mathrm{CDCl}_{3}\right) \delta 8.66(\mathrm{~s}, 2 \mathrm{H}), 8.26(\mathrm{~d}, J=8.0$ $\mathrm{Hz}, 2 \mathrm{H}), 8.11-8.08(\mathrm{~m}, 2 \mathrm{H}), 7.47$ (t, $J=8.0 \mathrm{~Hz}, 2 \mathrm{H}), 7.35-$ $7.27(\mathrm{~m}, 6 \mathrm{H}), 6.67-6.62(\mathrm{~m}, 4 \mathrm{H}), 3.92,3.19$ (two s, 6H), 3.70, 3.65 (two s, 6H), $2.78-2.72(\mathrm{~m}, 4 \mathrm{H}), 1.19-1.14(\mathrm{~m}, 24 \mathrm{H}) ;{ }^{13} \mathrm{C}$ NMR $\left(100 \mathrm{MHz} \mathrm{CDCl}_{3}\right) \delta 163.6,163.4,161.5,156.8,156.6$, 145.5, 145.5, 137.1, 137.0, 136.8, 136.2, 136.1, 134.0, 131.1, $131.0,130.5,130.0,129.4,128.8,128.8,128.2,128.2,127.9$, 127.7, 123.94, 123.91, 123.7, 121.8, 121.7, 121.6, 106.4, 99.80, 99.75, 55.9, 55.7, 55.6, 29.2, 24.2, 24.13, 24.11, 24.06; HRFAB $m / z$ 983.4292, calcd for $\mathrm{C}_{64} \mathrm{H}_{58} \mathrm{~N}_{2} \mathrm{O}_{8} \mathrm{~m} / z$ 982.4193. Anal. Calcd for $\mathrm{C}_{64} \mathrm{H}_{58} \mathrm{~N}_{2} \mathrm{O}_{8}$ : C, 78.19; H, 5.95; N, 2.85. Found: C, 77.83; $\mathrm{H}, 5.97 ; \mathrm{N}, 3.00$.

syn- and anti- $N, N^{\prime}$-Bis(2,6-diisopropylphenyl)-1,7-bis(2,5-dimethoxyphenyl)perylene-3,4,9,10-tetracarboxydiimide (4h). The reaction of $3(3.0 \mathrm{~g}, 3.5 \mathrm{mmol}), 2,5$ dimethoxyphenylboronic acid ${ }^{27}(3.78 \mathrm{~g}, 20.8 \mathrm{mmol}), \mathrm{Pd}\left(\mathrm{PPh}_{3}\right)_{4}$

(25) Belloni, M.; Manickam, M.; Wang, Z.-H.; Preece, J. A. Mol. Cryst. Liq. Cryst. 2003, 399, 93-114.

(26) Schmidt, J. M.; Tremblay, G. B.; Pagé, M.; Mercure, J.; Feher, M.; Dunn-Dufault, R.; Peter, M. G.; Redden, P. R. J. Med. Chem. 2003, $46,1289-1292$

(27) He, Z.; Craig, D. C.; Colbran, S. B. J. Chem. Soc., Dalton Trans. 2002, 4224-4235.
(100 mg, $2.5 \mathrm{~mol} \%$ ), and $\mathrm{Na}_{2} \mathrm{CO}_{3}(1.10 \mathrm{~g}, 10.4 \mathrm{mmol})$ in degassed EtOH $(3.5 \mathrm{~mL})$, benzene $(20 \mathrm{~mL})$, and $\mathrm{H}_{2} \mathrm{O}(10 \mathrm{~mL})$ under nitrogen at $80{ }^{\circ} \mathrm{C}$ for $16 \mathrm{~h}$ followed by column chromatographic purification on silica gel using toluene/ $\mathrm{CH}_{2} \mathrm{Cl}_{2}(2$ : 3 ) as the eluent produced $\mathbf{4 h}$ (two conformational isomers, 1:1 ratio) as a dark red solid $\left(2.5 \mathrm{~g}, 71 \%\right.$,): $\mathrm{mp}>350{ }^{\circ} \mathrm{C} \mathrm{dec} ;{ }^{1} \mathrm{H}$ NMR $\left(400 \mathrm{MHz}, \mathrm{CDCl}_{3}\right) \delta 8.64(\mathrm{~s}, 2 \mathrm{H}), 8.27(\mathrm{~d}, J=8.4 \mathrm{~Hz}$, $2 \mathrm{H}), 8.10-8.07(\mathrm{~m}, 2 \mathrm{H}), 7.46(\mathrm{t}, J=7.6 \mathrm{~Hz}, 2 \mathrm{H}), 7.31(\mathrm{~d}, J=$ $7.6 \mathrm{~Hz}, 4 \mathrm{H}$ ), 7.01-6.93 (m, 6H), 3.81-3.62 (four s from two different conformational isomers at $3.81(\mathrm{~s}, 3 \mathrm{H}), 3.79(\mathrm{~s}, 3 \mathrm{H})$, $3.66(\mathrm{~s}, 3 \mathrm{H}), 3.62(\mathrm{~s}, 3 \mathrm{H})), 2.78-2.70(\mathrm{~m}, 4 \mathrm{H}), 1.18-1.13(\mathrm{~m}$, $24 \mathrm{H}) ;{ }^{13} \mathrm{C} \mathrm{NMR}\left(100 \mathrm{MHz}, \mathrm{CDCl}_{3}\right) \delta 163.5,163.3,154.7,154.7$, 149.8, 149.6, 145.5, 145.5, 137.00, 136.95, 136.3, 135.8, 135.7, $133.9,131.92,131.87,130.4,130.3,129.5,128.7,128.6,128.4$, $128.3,128.2,123.9,121.93,121.87,116.3,116.2,114.4,114.2$, $113.2,113.1,56.4,56.3,56.0,55.9,29.24,29.21,24.18,24.15$, 24.1; HRFAB $m / z$ 983.4260, calcd for $m / z \mathrm{C}_{64} \mathrm{H}_{58} \mathrm{~N}_{2} \mathrm{O}_{8} 982.4193$. Anal. Calcd for $\mathrm{C}_{64} \mathrm{H}_{58} \mathrm{~N}_{2} \mathrm{O}_{8}$ : C, 78.19; H, 5.95; N, 2.85 . Found: C, 77.91; H, 6.03; N, 2.64 .

$N, N^{\prime}$-Bis(2,6-diisopropylphenyl)-1,7-bis(4-diphenylamino)phenylperylene-3,4,9,10-tetracarboxydiimide (4i). The reaction of 3 (3.0 g, $3.5 \mathrm{mmol})$, 4-(diphenylamino)phenylboronic $\operatorname{acid}^{28}(8.01 \mathrm{~g}, 27.7 \mathrm{mmol}), \mathrm{Pd}\left(\mathrm{PPh}_{3}\right)_{4}(100 \mathrm{mg}, 2.5 \mathrm{~mol} \%)$, and $\mathrm{Na}_{2} \mathrm{CO}_{3}(1.10 \mathrm{~g}, 10.4 \mathrm{mmol})$ in degassed EtOH $(3.5 \mathrm{~mL})$, benzene $(20 \mathrm{~mL})$, and $\mathrm{H}_{2} \mathrm{O}(10 \mathrm{~mL})$ under nitrogen at $80{ }^{\circ} \mathrm{C}$ for $72 \mathrm{~h}$ followed by column chromatographic purification on silica gel using toluene as the eluent produced $\mathbf{4 i}$ as a dark purple solid $(2.47 \mathrm{~g}, 60 \%): \mathrm{mp}>400{ }^{\circ} \mathrm{C}$ dec; ${ }^{1} \mathrm{H}$ NMR $(400$ $\left.\mathrm{MHz} \mathrm{CDCl}_{3}\right) \delta 8.83(\mathrm{~s}, 2 \mathrm{H}), 8.41(\mathrm{~d}, J=8.0 \mathrm{~Hz}, 2 \mathrm{H}), 8.23(\mathrm{~d}$, $J=8.0 \mathrm{~Hz}, 2 \mathrm{H}), 7.56-7.52(\mathrm{~m}, 6 \mathrm{H}), 7.42-7.35$ (m, 14H), 7.29$7.25(\mathrm{~m}, 10 \mathrm{H}), 7.12(\mathrm{t}, J=7.6 \mathrm{~Hz}, 4 \mathrm{H}), 2.73$ (septet, $J=6.8$ $\mathrm{Hz}, 4 \mathrm{H}), 1.26-1.24(\mathrm{~m}, 24 \mathrm{H}) ;{ }^{13} \mathrm{C} \mathrm{NMR}\left(100 \mathrm{MHz}, \mathrm{CDCl}_{3}\right) \delta$ 162.90, 162.88, 148.1, 146.6, 145.1, 140.6, 135.3, 134.6, 132.4, $130.1,129.7,129.5,129.4,129.22,129.19,129.1,128.8,128.0$, $124.7,123.7,123.6,123.3,121.8,121.4,29.5,24.42,24.37$; HRFAB m/z 1197.5306, calcd for $\mathrm{C}_{84} \mathrm{H}_{68} \mathrm{~N}_{4} \mathrm{O}_{4} \mathrm{~m} / z$ 1196.5241. Anal. Calcd for $\mathrm{C}_{84} \mathrm{H}_{68} \mathrm{~N}_{4} \mathrm{O}_{4}$ : C, 84.25; H, 5.72; N, 4.68. Found: C, 83.90; H, 5.78; N, 4.96.

Acknowledgment. We thank the National Science Council of the ROC, the Ministry of Education, the Ministry of Economy, and the RiTdisplay Corporation for financial support.

Supporting Information Available: ${ }^{1} \mathrm{H}$ and ${ }^{13} \mathrm{C}$ NMR spectra of $\mathbf{3}$ and $\mathbf{4 a - 4 i}$, CIF data, the ORTEP diagram for 3, and the MM2-calculated $X Y Z$ coordinates for the structures of $\mathbf{4 c - 4 f}$ and $4 \mathbf{i}$. This material is available free of charge via the Internet at http://pubs.acs.org.

\section{JO050001F}

(28) Pudzich, R.; Salbeck, J. Synth. Met. 2003, 138, 21-31. 